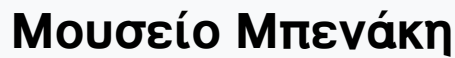

A Singular Antiquity: Archaeology and Hellenic Identity in Twentieth-Century Greece

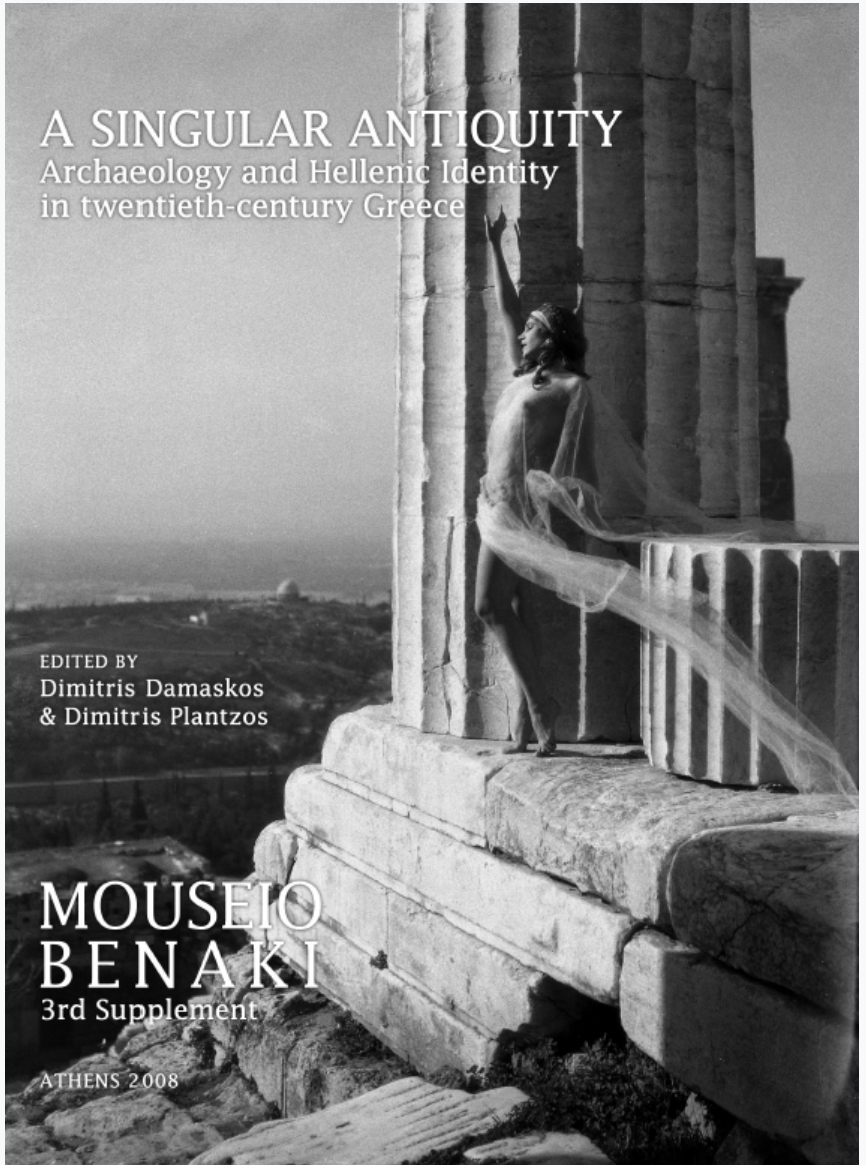

\section{National heritage and Greek revival: loannis Gennadios on the expatriated antiquities}

George Tolias

doi: $10.12681 /$ benaki.17972

Copyright @ 2018, George Tolias

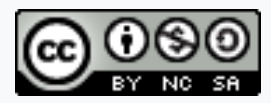

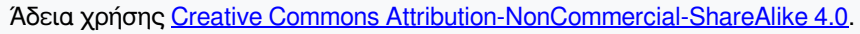

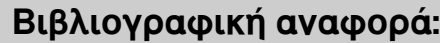

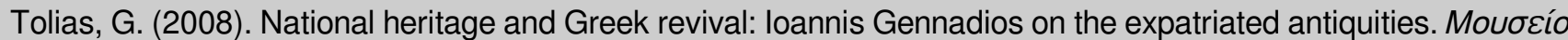

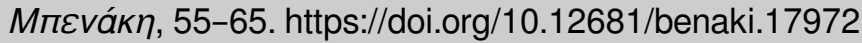




\section{National heritage and Greek revival: Ioannis Gennadios on the expatriated antiquities}

HELLENISM IS MOSTLY A MATTER of shared heritage. A synthesis of a diversity of elements itself, ${ }^{1}$ Hellenism transgressed the historical frontiers of Greek culture and evolved across cultural networks of uneven density of content and with divergent priorities. Indeed, Greek studies of all kinds form one of the oldest traditions in the academic culture of Western Europe and - during the eighteenth and the nineteenth centuries - a component of historical self-affirmation for the West. Furthermore, during this era, Hellenism engendered Philhellenism, the intellectual and political movement that promoted a utopian revival of the moral, cultural and political values of ancient Greece, and furthered Greek claims for independence. ${ }^{2}$ Although we may detect more or less veiled colonial if not imperialist motivations in Philhellenism, ${ }^{3}$ the Greek intelligentsia readily subscribed to it. Many Greek patriots and intellectuals adopted the ideas of Philhellenism and made ample use of the ancient heritage they shared with Western Europe in order to mobilize international sympathy and shape a modern Greek identity as part of the occidental construct. ${ }^{4}$

Greek intellectuals, backed by an international philhellenic vulgate, laboured for several decades in the nineteenth century in order to shape a convincing image for the emerging Greek nation. The implementation of the revivalist option in Greece, although in line with the demands of the time, was by no means a smooth operation. The process of hellenization, the attempts to create closer bonds with antiquity mainly in the fields of language and culture, upset and confused nineteenth-century Greek society. ${ }^{6}$ Archaeology was raised to the national science of the newly founded state. ${ }^{7}$ The fullest possible restoration of the ancient monuments, those on the Athenian Acropolis in particular, was seen as the outstanding symbol of the revival of Greece. ${ }^{8}$ Furthermore, friction was soon evident between national and international attitudes towards the Greek heritage. Criticism from foreign scholars was met with hostility, and there are still issues where the tension between the foreign and the domestic position on the Greek heritage is obvious. ' One of these is the question of the antiquities removed from Greek territory and dispersed to public and private collections all over the world.

The Greek reaction to the exportation of antiquities from Greek territory was slow in coming. Indeed, in the early stages, most of the informed thinkers such as Moustoxidis and to a certain degree, Korais, preferred to remain silent on the issue, recognizing the benefits of the antiquities frenzy for the Greek national cause. ${ }^{10}$ Despite these silences, the explicit stance on the issue has remained firm ever since it was first expressed, immediately after the creation of the Greek state. The early collecting of Greek antiquities has always been considered as plundering, an act of repeated vandalism that deprived modern Greeks of their national cultural heritage. The issue is a complex one with deep ideological and political implications. From one point of view, that of ideology, the Greek position reflects the urge to retake possession of the past and to restore its unity by gathering its dispersed elements. From another point of view, the political, the newly created Greek state was using the antiquities in order to obtain international political or economic advantages. At the same time, the Greek state facing avid unauthorized treasure-hunters and 


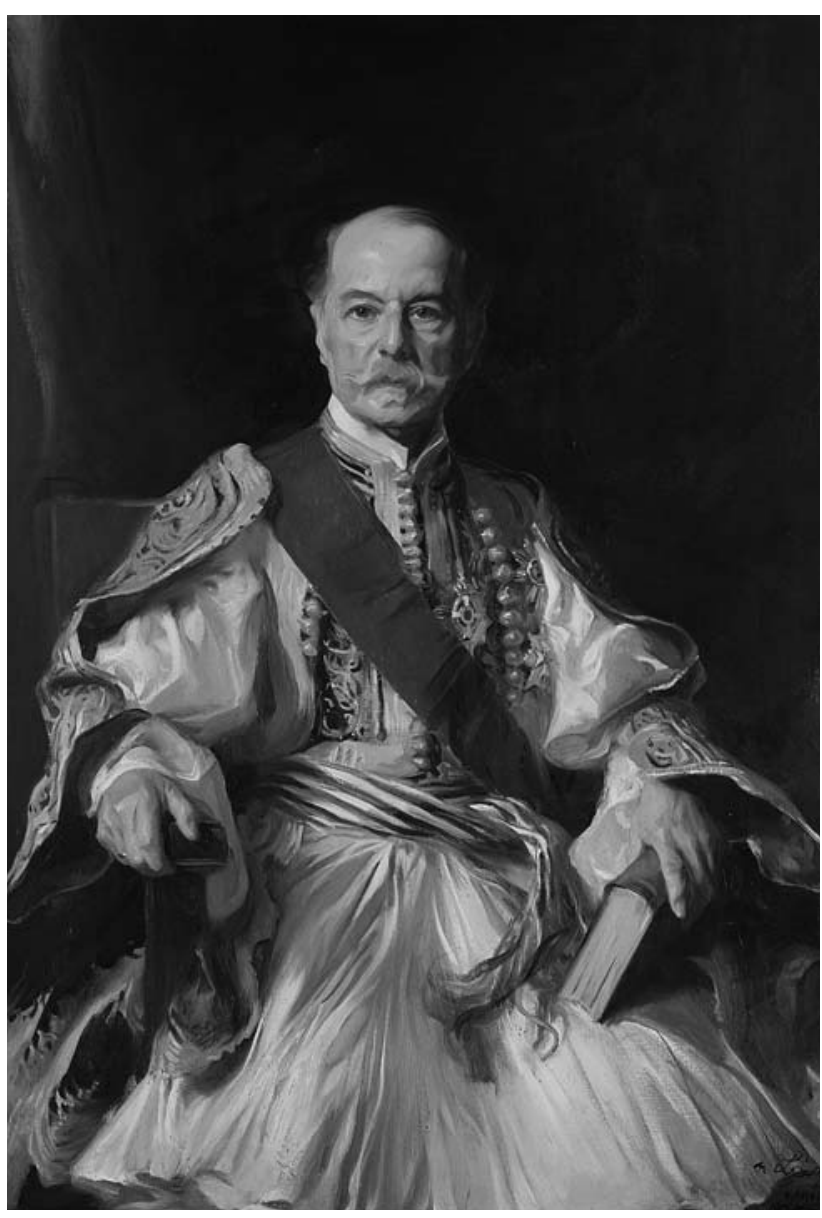

Fig. 1. Ioannis Gennadios as a Philhellene, by De Lazlo, 1925 (photo: The Gennadeion Library, Athens).

intense pressures from the foreign archaeological missions for more licence and privileges. ${ }^{11}$

Much has been written in Greece on the dispersal of Greek antiquities, since the very outset of Greek independence. Most of these texts relate directly or indirectly to the so-called Elgin Marbles, and are often poorly written, in the characteristic tone of a dithyramb or lament. ${ }^{12}$ However, it would not be amiss to note that, apart from the issue of the Elgin Marbles, the study of the dispersal of Greek antiquities has not yet become a subject for Greek historiography. ${ }^{13}$ The case is considered inflammatory, for the question has taken on political dimensions ever since the official request for the return of the Parthenon Marbles. The subject always irritates the collective sensitivity, and the Greek mass media systematically present antiquities issues as being of the utmost national impor- tance, thereby keeping Greek public opinion in an ever watchful state. At the same time, the fact that antiquities are actually the object of an illicit worldwide traffic links their trade with questions of international criminal law, throwing a shadow of suspicion over even the associated activities of the past.

The presence of the issue on the political agenda, combined with the absence of a modern analysis supporting the claim, has resulted in the revival of old and largely outdated works, such as Antonios Miliarakis' On the Elgin Marbles, first published in 1888 and reissued in $1994,{ }^{14}$ or Ioannis Gennadios' Lord Elgin and Earlier Antiquarian Invaders in Greece, 1440-1837 (A Historical and Archaeological Treatise). ${ }^{15}$ The fate of this last book is indicative. Although published in 1930, copies of the first edition of the book were still available in bookshops up to the early eighties. The official request for the return of the Elgin Marbles by Melina Merkouri endowed the aged treatise with renewed popularity: a new reprint of the work appeared in 1985 while its adaptation to demotic Greek ran to two successive editions (2003 and 2006). ${ }^{16}$

Gennadios' aim was to provide the Greek claim on the marbles with solid historical arguments. Familiar with a bibliography as rich as it was old, Gennadios approached the thorny question of the dispersal of Greek antiquities from the Greek nationalist point of view. However, his ideological basis was already obsolete. Although written in 1930, the Treatise epitomizes the Greek opinions on the Greek revival of the early nineteenth century. The creation of the modern Greek state was understood and promoted as a 'regeneration' (palingenesia); modern Greeks were considered as natural, cultural, and territorial heirs to the ancient legacy and therefore the sole responsible for its preservation.

Gennadios epitomizes the militant patriotic tradition of nineteenth-century Greece. The son of the scholar Georgios Gennadios, Ioannis was born in Athens in 1844, educated at the Malta Protestant College and then settled in London. His diplomatic career began in 1871, after the publication of an apology for the Dilessi murders, ${ }^{17}$ which cost him his position in the commercial firm owned by the Rallis Brothers. As a diplomat, Gennadios was posted to The Hague, Washington, Constantinople, and London. An erudite bibliophile, he put together a significant personal collection of 24,000 books which was to become the core of the Gennadios Library. He married Florence 


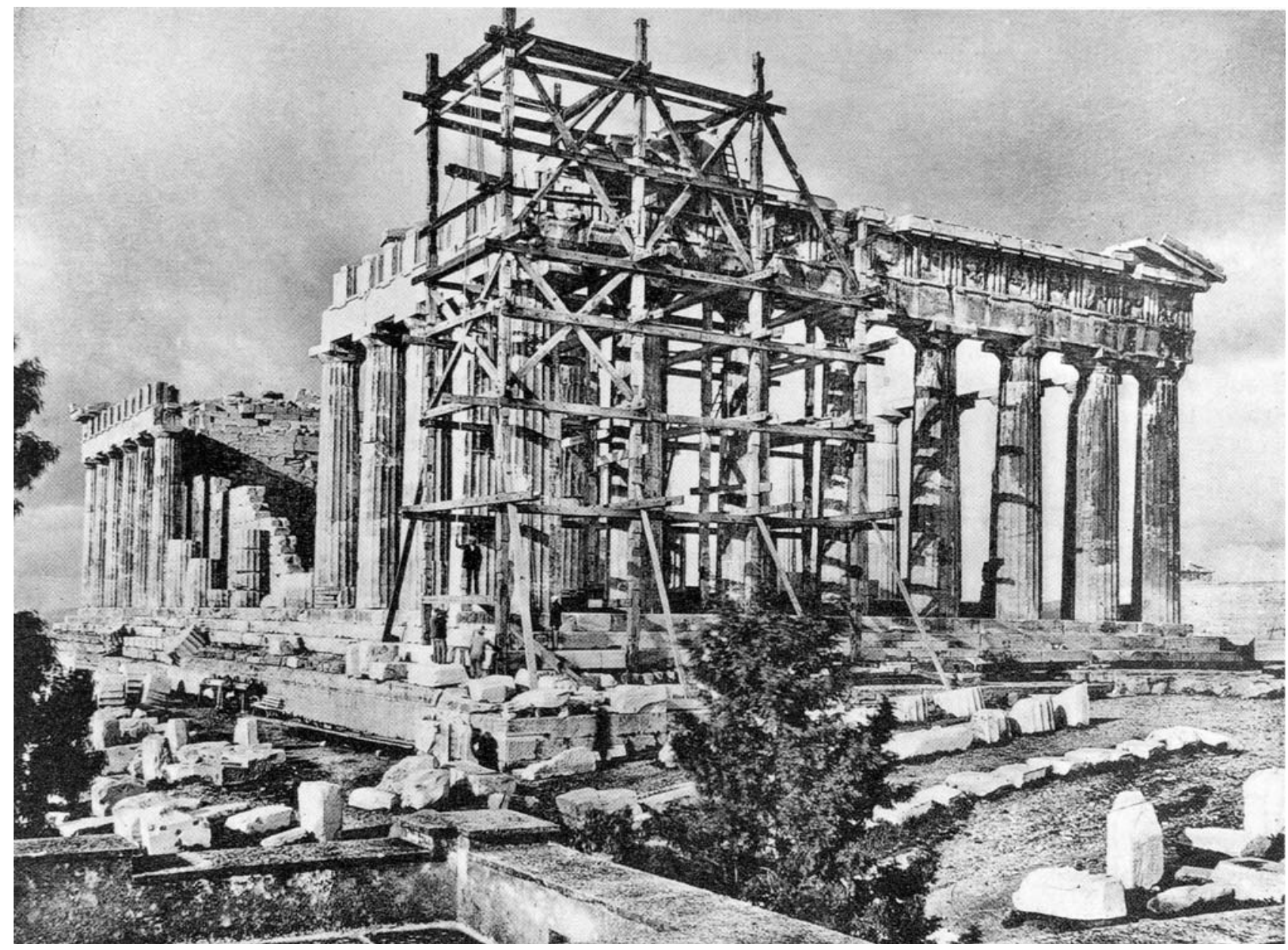

Fig. 2. Restoration and reconstruction works on the Acropolis ca. 1930 (photo: N. Balanos).

Laing Kennedy (1902) and he died childless at 'White Gates', his home at East Molesey in Surrey on 7 September $1932 .{ }^{18}$ With him died a legacy of radical Greek patriotism inspired by antiquity, a cultural and political tradition that connected modern Greece and Europe through the revival of Greek heritage, which invested in Greek studies, and nourished the idea of a renaissance of the political, moral and cultural values of Greek antiquity (fig. 1).

Lord Elgin and Earlier Antiquarian Invaders in Greece was written in England, where Gennadios spent the final years of his life. It was published two years before his death, in 1930, when Gennadios was 86 years old. The book, 260 pages in quarto, was published by the Archaeological Society at Athens. In his preface, the author declares this work to be his personal contribution to the celebration of the centenary of Greek revival. Thus, the three key notions he provides us with to approach his work are 'history,' 'archaeology,' and 'patriotism'.

Gennadios was not a historian but a diplomat and prolific as a militant polymath author, writing on various political and cultural issues. Fully familiar with the literature of foreign travellers in Greece - which formed the core of his vast library - he developed his own, empirical approach. The Treatise resembles a collection of written testimonies rather than a historiographic composition. It is a survey of Western antiquarian collecting activities in Ottoman Greece, presenting 75 cases of looting in 75 short chapters. Each chapter contains the relevant testimonies with concise commentaries. Gennadios emphasizes the methods used in the removal and exporting of antiquities. He deals selectively with their later fate and their dispersal, especially when they ended up in important public or 
private collections, as was the case with the Arundel Marbles, the Morosini lions, the Elgin Marbles, the antiquities of Aphaea and Bassae, and the Venus de Milo. Apart from the primary sources, which account for the greater part of the material, Gennadios also relies on the recent catalogues of the British Museum, A. Hamilton Smith's essay on Lord Elgin's collections, ${ }^{19}$ Michaelis' study on the antiquities collections in Great Britain (1882), ${ }^{20}$ and Antonios Miliarakis' work on the Elgin Marbles (1888). ${ }^{21}$

The innovation proposed by Gennadios' Treatise lies primarily in the wide historical spectrum of his investigation covering a timeline from 1440 to 1837 . The Treatise is divided into two parts and follows a reverse chronological order. In the first part, the author deals with the issue of the Elgin Marbles, and provides detailed commentary on the evidence relating to the sale and its aftermath. The second part of the Treatise contains a brief account of foreign archaeological activities, from Cyriac of Ancona (1440) to the episode of the transporting of the Venus de Milo to the Louvre (1820). The date given as the end of his history (1837) must be related to the founding of the Archaeological Society at Athens. ${ }^{22}$ This is not a typographical error, but an indirect insinuation that the Archaeological Society had imposed limits on the foreign collecting of Greek marbles, thus launching an unofficial campaign for their national preservation. ${ }^{23}$

The Treatise is dedicated to the memory of his father, Georgios Gennadios, 'who transmitted to his students the burning torch of the intellectual and moral heritage of our fathers and the affectionate care for the remains of their divine art. ${ }^{24}$ Indeed, Georgios Gennadios had been the first to take measures for the protection of antiquities, with the founding of the first Museum in Aegina. The introductory chapter of the Treatise is an odd text, in which Gennadios relates the details of his acquisition of the manuscripts of Ioannis Benizelos, an eighteenthcentury Athenian chronicler and an ancestor of his on his mother's side: ${ }^{25}$ 'I became the master of this heirloom of my mother's family', he rejoices. 'The wishes of the virtuous and god-fearing Ioannis Benizelos had not allowed his legacy to fall prey to a stranger'. ${ }^{26}$

The work closes with a chapter entitled 'Concerning the Return', which contains the latest discussions about the Greek claim to the Parthenon Marbles (1927-29). In this last chapter, Ioannis Gennadios recommends the tactic which - in his opinion - should be adopted: an incremental return of the marbles, beginning with those architectural members necessary to the restoration of the Parthenon, a project then in progress under the supervision of Nikolaos Balanos (fig. 2). ${ }^{27}$

Naturally, Gennadios assured his readers that the Treatise was written from an objective standpoint, untainted by the passion found in other comparable works of the period, such as the bitter demands for the return of the Marbles published by A. Philadelpheus on 6 of June 1927, whose tone Gennadios judged ineffectual. ${ }^{28}$ Gennadios' objectivity is in fact limited to commenting on, and occasionally quoting, viewpoints that do not coincide with his own. His attitude toward the issue is certainly not objective, for he is absolutely convinced of the rightness of his position and of the guilt of the protagonists of his narrative. They, or their agents in Greece, are condemned, and no attempt is made to analyze events historically, taking into consideration the cultural priorities and the historical maturity of each age. Gennadios pulls no punches, and makes no effort to mitigate his rage. One characteristic example is his stance towards Francesco Morosini, whom he considers responsible for the destruction of the Parthenon in the siege of 1687. With his irritation exacerbated by the political tension between the two countries and the Italian occupation of the Dodecanese, Gennadios calls the Venetian admiral 'the Italian criminal,' and describes the collecting activities of his officers in the following words: 'But the invaders fell like crows even upon the ruins, each looting whatever he could carry, the one seizing a statue head, another taking part of the frieze, a third taking an inscription. Some of this sinful plunder survives even today in public museums, and the archives of Venice still have a copy of Morosini's report to the Senate, in which he describes, with cool - if not brutish - indifference, his act of vandalism'. ${ }^{29}$

\section{Restoring Hellenism}

Although Gennadios' Treatise comes several decades after those by Michaelis and Miliarakis, it overlooks the innovation in both their approaches. Miliarakis treated the issue with remarkable composure. He implied that the case was closed ('the event already belongs to history') and had shown the direction for future investigations: 'it is incontestable, that this narrative, however regrettable, belongs to the local history of Athens under Turkish rule, and to 


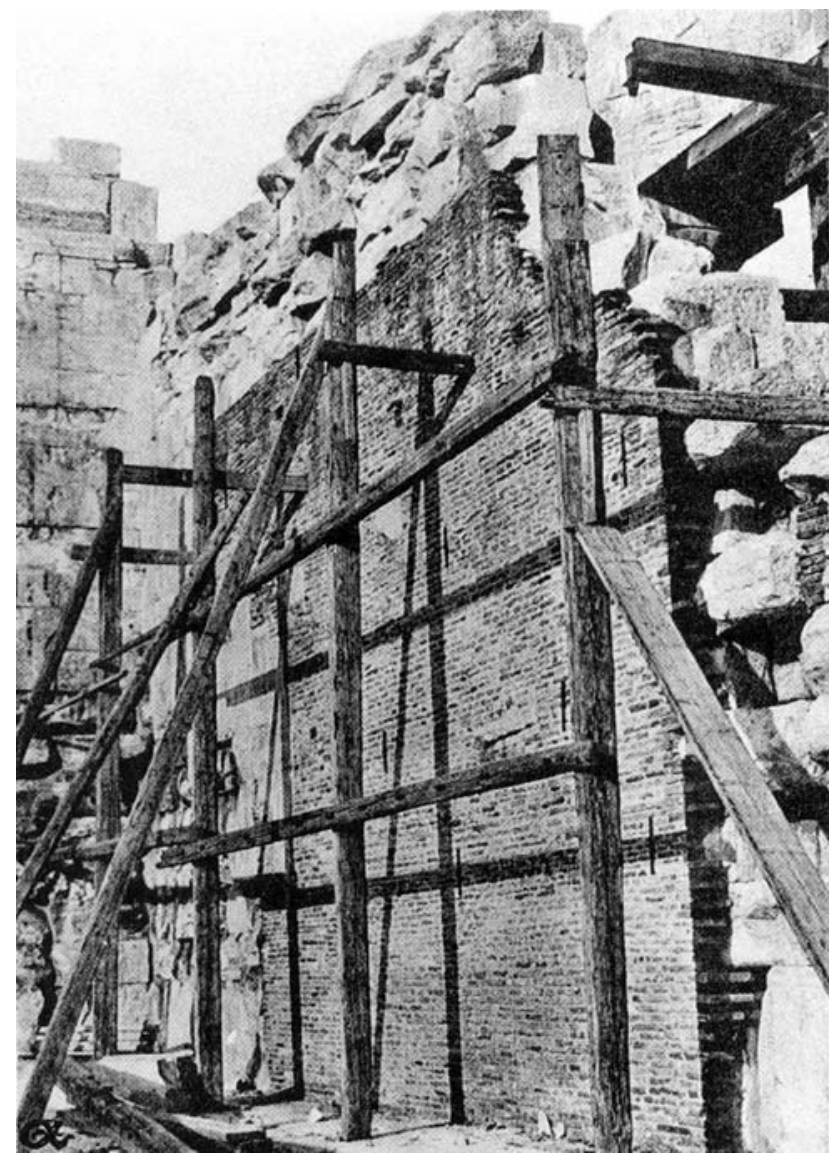

Fig. 3. Restoration and reconstruction works on the Acropolis ca. 1840 (photo: N. Balanos).

the specific history of the fortunes, adventures, and peregrinations of Greek antiquities, if such a history is ever to be written'. ${ }^{30}$ For his part, Michaelis had already cleared a new path for research by recording and documenting the historical collections of Greek antiquities in Great Britain.

Gennadios cherished the idea of gathering the disjecta membra of Greek culture in order to restore its lost unity. Indeed, we could view his collection of foreign documents on Greek history and the offer of his collection to the Greek public in this light: as an effort to assemble the dispersed testimonies to Greek history and culture, to recreate a coherent whole and to repatriate it. His patriotism, nourished by the ideas of the Greek revival, did not allow him to face the phenomena he studied as part of another and more important - mechanism of cultural transfer, i.e. humanist efforts to preserve the Greek cultural heritage, something that Korais, the instigator of the revival theory in Greece, had boldly acknowledged. For Korais, the collecting of Greek manuscripts and antiquities was part of a longstanding tradition of scholarship, that would contribute, in the long term, to rescuing the ancient heritage and integrating it into the Western cultural identity. ${ }^{31}$

Gennadios does not refer to the process by which Greek antiquities had become the objects of a new veneration. ${ }^{32}$ He focuses on the procedures, overly critical of the processes by which antiquities were removed and transported, always emphasizing the destruction caused by these early collecting practices. Gennadios was not concerned with the increasing importance of Greek antiquity in Western historical awareness and the resulting discovery, identification, collection, and historical classification of its material remains. ${ }^{33}$ His intention was to support the Greek claims, and to stigmatize those practices which he personally considered not only unilateral (colonialist or imperialist, as we might say in another context), but, above all, vandalistic. Gennadios approached the Humanists' collecting practices with a new unilateralism, that of Greek nationalism.

Nor does Gennadios seem to sense in his Treatise that ancient Greek material remains could be considered as part of a universal cultural heritage. For him, they represent an exclusive national cultural heritage: the Greeks are the ones responsible for their preservation and restoration. In this he shares the position adopted by the members of the Archaeological Society at Athens. Gennadios recalls with tenderness and affection these stewards of the past: Finticlis 'the genuine Athenian with his Attic salt', Efstratiadis 'the polymath', Koumanoudis 'the kind aristocrat, nourished by the Muses', Ragavis 'the inspired student of George Gennadios'. All of them had fought the good fight against 'the thieves of antiquities and the admirers of foreigners'

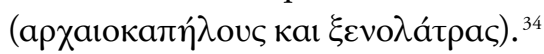

Gennadios reproduced in full the legendary speech delivered by the secretary of the Archaeological Society, Alexandros Rizos Ragavis ${ }^{35}$ on 12 May 1842, at the Parthenon, before the assembled members of the Society. ${ }^{36} \mathrm{It}$ is the manifesto of the Greek revival pronounced before an audience of antiquarian scholars and patriots inspired by Greek antiquity.

In this speech, Rizos Ragavis expressed his regret that so many ancient monuments had remained visible for centuries, attracting the interest of foreigners. According to Ragavis, as quoted by Gennadios: 'The faithful earth of Greece would have preserved them in its womb and 
returned them to their ancient position of glory, as the race of the Greeks preserved the buried spark of freedom, lighting it bright and active once again in the fullness of time $^{37}$

Turning to the restoration of the Parthenon, Rizos Ragavis proclaimed:

'We are gathering every stone of it as though it were a diamond, every fragment a relic. And erecting one of those machines around it to resurrect it, using the very same scaffolds Lord Elgin employed to take the temple apart. And let Europe, as witness to our deeds, judge whose efforts are nobler and more deserving of her sympathy and aid. [...] And, as a formal protest against its desecration, we shall resurrect it from its surviving ruins today, as we have resurrected free ancient Greece from its surviving remains...' .38

The construction of the modern Greek state was fused with the restoration of antiquity in this rhetoric, and the resurrection of the most prominent of the inherited monuments, the Parthenon (by 'gathering every stone of it'), was becoming the emblem of the rebuilding of the Greek nation (fig. 3). Gennadios embraces the same rhetoric, merging ancient monuments with modern Greeks: the foreign collecting practices have left them both 'wronged and stripped'. Antiquities and modern Greeks are one in this rhetoric, for they are both the extant remains of glorious antiquity, vehicles of the same values; they have both come to the surface of history after long centuries of oblivion.

Restoring their heritage by gathering its dispersed elements was the task of modern Greeks. Gennadios, a true patriot and a practical man, does not bother stating the obvious. He expresses the common beliefs of his age, or rather of the age in which he developed his position towards these issues: the shared Greek character of both surviving monuments and modern descendants of ancient Greeks is for Gennadios a simple and direct matter. It is the modern Greek adaptation of 'Hellenism', the key notion of the adoption of the revival theory in Greece. ${ }^{39}$ Konstantinos Dimaras has defined this extrapolated perception of Hellenism as 'the idea of the existence of a particular entity which connects the totality of all sorts of elements emanated from the Greeks and scattered in space and time.'. ${ }^{40}$ Hellenism becomes thus the defining and transcendent characteristic of Greeks, a product of the ceaseless interac- tion between history and geography, culture, and landscape. This forms the basis of his argument. For instance, when commenting on the modern Athenian legend of the lament of the Caryatids for their captured sister, ${ }^{41}$ he says:

'But what man with a heart has not been moved to tears reading about that most poetic of Athenian traditions, equal to the most beautiful myths of ancient Greece - that the Korae of the Acropolis nightly mourn the abduction of their sister, and that she answers them from her prison down in the city. Only a people that preserve its nationhood vigorously and trustily, a people with an inborn dignity and self-awareness, only a genuinely Hellenic spirit could ever formulate such a marvellous expression of its anguish. [...] Myths! Yes. But they are the creations of nobler hearts, the offspring of stronger intellects, and the enchanting songs of more authentic Hellenes than the venal practices of our modern antiquity thieves. ${ }^{42}$

Greek Hellenism, the 'genuinely Hellenic spirit', becomes the hallmark that distinguishes the dispersed manifestations of the Greek civilization, and at the same time differentiates the universal heritage of Hellenism from the national Greek heritage. Gennadios' central argument is that the legal and natural heirs to the expatriated antiquities are the modern Greeks, racial and territorial heirs of the ancients. The shared Hellenism of both modern and ancient Greeks is 'genuine' and 'inborn' if not hereditary. It is related to the specific geographic and climatic conditions of the land. Here we have the old Hippocratic view of human incarnation in the natural environment, as understood by the anthropology of the Enlightenment. ${ }^{43}$ This view was applied to cultural matters, including Greek ones, by Robert Wood in $1775,{ }^{44}$ and systematically used by Korais in constructing the national rhetoric of the revival of 'free Greece'. ${ }^{45}$ It was further enriched by Byron with Romantic notions about the effect of light and the atmosphere. In fact, Byron was the first to speak of the exile of the ancient gods to Hyperborean darkness and fog, and of their misery away from the soil, climate, and light that had borne them..$^{46}$ This commonplace would be repeated for decades, and even renewed at the end of the century by Renan. In his Prayer on the Acropolis, the Greek spirit (génie) is only perceptible in situ, under the specific conditions of the Greek climate and landscape.

The shared Hellenism of ancient monuments and mod- 
ern Greeks was thus defended by the notion of territoriality, one of nationalism's key notions. ${ }^{47}$ Gennadios quotes ample passages supporting this position. One of the most eloquent is that offered by Quatremère de Quincy: 'Instead of forcing them [the antiquities] to migrate to the Hyperborean lands, what benevolent power would restore them to their homeland? Where the sky, the earth, the climate, the lines of nature, the images, the buildings, the games, the festivals, the costumes remain, even today, in harmony with ancient sculpture. ${ }^{38}$

Hellenism and, later on, Hellenicity as expressions and manifestations of Greek territoriality, ${ }^{49}$ are deeply rooted commonplaces in the poetic of Greek nationalism. They reached a peak in the works of Kostis Palamas and Angelos Sikelianos, and were then passed on to successive generations. Let us remember Melina Merkouri, who in 1982 requested the return of the Elgin Marbles 'to the blue sky of Greece', quoting from Yannis Ritsos' Romiosyni: 'these stones are not content with less sky'. ${ }^{50}$

Gennadios cherished the idea of international recognition of the revival of Greek antiquity in modern Greece, an emblematic expression of which was the return of the expatriated monuments and the fullest possible restoration of the remaining ruins. The domestic implications of the issues were more intense however: antiquities - long since invested with symbolic signification $-{ }^{51}$ were imposed on Greece as a dominant category articulating key notions of memory, race and territory, thus becoming vectors of identity. ${ }^{52}$

Antiquities symbolized the ancient seed in the faithful earth of Greece', which would once again give birth to the moral and cultural values of a free Greece, in a modern version of the myth of Deucalion. Revival is a humanistic devise. It supposes the recurrence of historical segments within a cyclical conception of time. Thus, the intervening fate of the antiquities, and the successive uses to which they had been put, were treated by Ioannis Gennadios as regrettable episodes. Gennadios attempted to compose above all an essay on the forced expatriation of Greek antiquities, without any real concern for the historicity of the phenomena he was studying. Like Ragavis before him, he would have liked, if possible, to annul the historical process; he would have liked the monuments to be buried in the earth and reborn with the Greeks of the nineteenth century.

The international dimension of the Greek cultural heritage was nevertheless a reality that Gennadios could not ignore. He acknowledged the importance of the work done by foreign archaeologists, members of the foreign schools at Athens, yet he was irritated by their arrogance. Indeed Gennadios valued the work being accomplished by the foreign schools - after all, it was to one of these that he entrusted his collection of books. ${ }^{53}$ However he expressed his discomfiture with the colonial-style conditions prevailing in Greek archaeology during the inter-war period. According to him Greeks should be the only arbiters and managers of archaeological policy, and he requested:

'[...] that the number of licenses granted be limited [...] that we request that our willing courtesy be reciprocated, to a certain degree, for instance by granting us the privilege of excavating some of the famous Greek cities of Magna Graecia. [...] These are fundamental obligations, a trifling exchange for the valuable privileges, services, and opportunities that we so generously and readily provide, even to the representatives of countries that allow no foreigner to perform any such research on their lands'.

And, remembering his ('red-faced') indignation at seeing French signs at the archaeological site of Delphi, he concludes: 'and overall, what must determine our relations with foreigners is an unassuming but steadfast sense of dignity and of our rights as Greeks. ${ }^{54}$

It would be easy to dismiss the positions adopted by Gennadios in 1930 as the romantic ideas of an aged radical patriot. Nevertheless they express the tension between two conflicting perceptions of Hellenism, due to an extrapolation of the revivalist philhellenic discourse within the Greek national context, its assimilation, and its implication in the construct of modern Greek identity. Nor should we dismiss Gennadios' ideas as outdated. Although the revival option was challenged in the second half of the nineteenth century, ${ }^{55}$ this does not mean that antiquity lost its role as the foundation and central reference of the Greek identity. ${ }^{56}$ The revivalist ideas persisted, and their underground perpetuation resulted in their sudden and repetitive reappearance. ${ }^{57}$

Gennadios' patriotic attachment to Greek antiquity maintained a significant and somewhat contradictory tension between the national and the global aspects of the issue. His approach was in line with the demands of the time for national self-affirmation, a rebuilding of the 
cultural and historical unity of the Greek nation. Within this scheme the expatriated antiquities and their return functioned as an allegory for rebuilding Hellenism from its elements, dispersed in space and time.

What should be stressed, finally, is that - despite the fractious tone and the radical patriotic determination Gennadios was confronting a legitimate historical problem in his own way. The collecting practices that had gradually developed around Humanist interest in the Greek past had a code of ethics, which was not always respected. One of the key features in this code had to do with the nature of antiquities, whether they were portable or fixed to some ancient monument. Thus Lord Elgin's policy was immediately condemned as 'looting' by the British liberals:

\section{Notes}

1. See the definition by Pierre Grimal: 'L'hellénisme est une abstraction, qui sous-tend une grande diversité de forces créatrices, volontiers anarchiques, apparaissant au sortir de la préhistoire et qui vont s'épuisant, après une floraison magnifique étendue sur quatre ou cinq siècles. Après quoi l'hellénisme est matière d'héritage et continue de vivre à l'intérieur des sociétés et des cultures qu'il a fécondées ou suscitées', in: Finley \& Bailey 1992, 3 .

2. For a definition of Philhellenism, see Espagne \& Pécout 2005,5 .

3. These attitudes are plainer in the Russian Philhellenism of the late 18th c. (see Venturi 1979, III 3-153) or the French philhellenic positions in the period 1797-1815 (see Rodokanakis 1899).

4. See Dimaras 1982, 333-59; Skopetea 1988, 163-74; Tolias 1997, 435-94.

5. For the gradual Hellenization of Greek lands see Tolias 2003a; Augustinos 2002.

6. See Gourgouris 1996, 122-54 ('The punishments of Philhellenism').

7. Hamilakis \& Yalouri 1999.

8. Yalouri 2001. The restorations caused the destruction of the remains from all the intervening periods.

9. See Grivaud 2001; Gourgouris 1996; Veloudis 1982; On the critique of Philhellenism at the end of the 19th c., see Basch 1995, 493-500 ('Le Misophilhellénisme') and Tolias 2008.

10. On Greek reactions to foreign antiquarian activities, see Tolias 2003b, 172-78. Korais' reaction in 1807 related mainly
'I do not believe that the honour of England is served by the looting of India or Athens', Byron declared in 1812. The discussion over the return of Napoleon's art plunder to Italy opened the question of an international agreement on cultural heritage: in the parliamentary debate of 1816 over the purchase of the Elgin collection by the British state, British liberals constructed their arguments around notions of international legality, the abuse of power, and the question of the 'natural' beneficiaries of antiquities.

\section{George Tolias}

Institute for Neohellenic Researches National Hellenic Research Foundation gtolias@eie.gr

to the protection of Greek manuscripts. In his introduction to Isocrates (Korais 1807; reissued 1833, 251), he acknowledges the service done to Greece by humanist collectors of Greek manuscripts and announces the new attitude that the nation should adopt: 'From now on we neither offer nor trade the property of our ancestors'.

11. See Kokkou 1977; Amandry 1992; Kalpaxis 1990; Kalpaxis 1993; Kalpaxis 2000.

12. Simopoulos 1993, offers an eloquent example of this type of Greek patriotic historiography.

13. For some exceptional attempts, see the analyses by Yalouri 2001 and Gazi 1990.

14. Miliarakis 1994.

15. Gennadios 1930.

16. Gennadios 2003.

17. See Jenkins 1961.

18. On Ioannis Gennadios, see Walton 1964.

19. Hamilton Smith 1916, 163-372.

20. Michaelis 1882 .

21. Miliarakis 1994.

22. On the Archaeological Society at Athens, see Kavadias 1990.

23. On the preservation of antiquities in 19th c. Greece, see Kokkou 1977.

24. On the activities of Georgios Gennadios, related to the protection of antiquities, see Velianitis 1993, 275-88. See also 
the biographical note composed by his son Ioannis Gennadios, under the name Xenophon Anastasiadis (1901).

25. Gennadios' introductory digression is due to the fact that the last entries in Benizelos' Ephemerides refer to the visit of Elgin to Athens, and are in fact the earliest Greek record of it. 'I have rarely felt my heart beating more vigorously or joyfully', he writes when he sees the announcement that the manuscripts were going to auction. 'By inspiration, I discovered the treasure. I immediately began to search for it, as though on a pilgrimage, and all my suspicions were confirmed. Before me lay the manuscript, over a hundred years old, written by my own greatgrandfather'. Benizelos' works were finally published in 1986, with an extensive introduction by Ioannis Gennadios.

26. Gennadios 1930, viii.

27. See Balanos 1930; Balanos 1938.

28. Gennadios 1930, 19.

29. Gennadios 1930, 184-85. On the collections of Greek antiquities in Venice, see Beschi 1972-73; Franzoni 1984; Favaretto \& Ravagnan 1997; for the functions of the antiquities brought by Morosini, see Stouraïti 2003, 179-98.

30. Miliarakis 1994, 36.

31. See n. 10 above.

32. Gran-Aymerich 2007; Schnapp 1993; Étienne \& Étienne 1990.

33. Weiss 1988; On the notion of cultural heritage as historical concept, see Hartog 2003, 163-206.

34. Gennadios 1930, 141. Stefanos Koumanoudis (18181899), Secretary of the Archaeological Society after Ragavis (and for 36 years), treated foreigners with the same animosity. This was not the general attitude of the administrators of the Archaeological Society. Alexandros Rizos Ragavis had been more flexible. See Matthaiou 2006-2007, 193-94.

35. Alexandros Rizos Ragavis (1809-1892) was the Secretary of the Archaeological Society at Athens till 1850. On Alexandros Rizos-Ragavis, see Soulogiannis 1995.

36. Gennadios 1930, 142-46.

37. Gennadios 1930, 144.

38. Gennadios 1930, 145.

39. 'Hellenism' ( $\varepsilon \lambda \lambda \eta v i \sigma \mu o ́ c)$ is the term used in the early 19 th c. to define the distinctive character of Greek culture. It was replaced by the term 'Hellenicity' ( $\varepsilon \lambda \lambda \eta \nu$ เкó $\eta \tau \tau)$ by the end of the century when the national historical narrative incorporated Byzantium and the popular traditions in the series of modern Greek cultural references. See Dimaras 1975; Said 1991.
40. 'L' hellénisme [...] est l' idée de l' existence d' une entité particulière qui réunit à travers le temps et à travers l'espace la totalité des éléments de toutes sortes qui ont émané du peuple hellène' (Dimaras 1975, 557).

41. On the legend, see Kambouroglous 1910-1912.

42. Gennadios 1930, 134-35.

43. See Cantor 2002.

44. Wood 1775.

45. Korais 1803.

46. Byron, Childe Harold's Pilgrimage, Canto II 15.

47. There is an abundant bibliography on the relations between territoriality and nationalism, starting with the pioneer study of Gottmann 1973. See also Anderson 1983; Sack 1986; White 2000.

48. Gennadios 1930, 122.

49. Tsaousis 1983, 15-16; Tziovas 1989.

50. M. Mercouri, Speech in Mexico City, 29 July 1982; quoted by Étienne \& Étienne 1990, 139.

51. Collected antiquities are defined as 'sémiophores' by Krzystof Pomian (Pomian 1987, 15-59; Pomian 1995, 215).

52. See Hartog 2003, 164.

53. The choice of a foreign school as keeper of his collection should not surprise us. Gennadios was above all a pragmatist and fully aware of the conditions in Greek state institutions. In the late twenties, when he entrusted his library to the American School of Classical Studies, the United States of America was a non-colonial power.

54. Gennadios 1930, 233-34.

55. By the current of demoticism, inspired by vernacular culture as well as by new social realities. See Iliou 1989; Tziovas 1989; Stavridi-Patrikiou 1999. At the same time the national historiography proposed the idea of the historical continuum of the Greek nation, adding the Byzantine Empire to the ancestors of the nation. Motivated by new political priorities, the revival of antiquity was gradually replaced by notions of a Byzantine revival. For the relevant bibliography, see Argyropoulos 2001.

56. Dimaras 1975; Kitromilides 2003.

57. For its effects on the 20th c. ideological debates, see Iliou 1989; on modern Greek society, see Herzfeld 1987; on archaeology, see Shanks 1996. 
REFERENCES

Amandry P. 1992: Fouilles de Delphes et raisins de Corinthe: histoire d'une négociation, in: R. Etienne (ed.), $\mathrm{La}$ redécouverte de Delphes (Paris and Athens) 77-128.

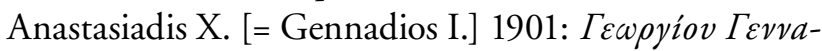

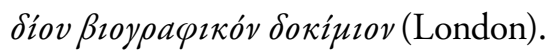

Anderson B. 1983: Imagined Communities: Reflections on the Origin and Spread of Nationalism (2nd revised edition; London and New York).

Argyropoulos R. 2001: Les intellectuels grecs à la recherche de Byzance (1860-1912) (Athens).

Augustinos O. 2002: Hellenizing Geography: Travellers in Classical Lands 1550-1800, in Gerald S. (ed.), The Classical Heritage in France (Leiden, Boston and Cologne) 9-24.

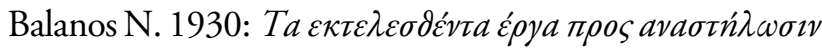

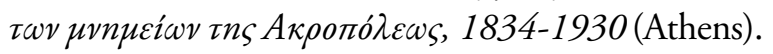

Balanos N. 1938: Les Monuments de l'Acropole. Relèvement et Conservation (Paris).

Basch S. 1995, Le Mirage Grec. La Grèce moderne devant l'opinion française (1846-1946) (Paris and Athens).

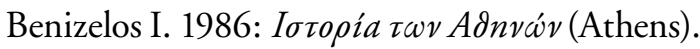

Beschi L. 1972-73: Antichità cretesi a Venezia, Annuario della Scuola Archeologica di Atene 50-51, 479-502.

Cantor D. 2002 (ed.): Reinventing Hippocrates (Aldershot).

Dimaras K.Th. 1975: Ambivalence de l'Hellénisme, in: Actes du VIe Congrès de l'Association Internationale de Littérature Comparée (Stuttgart).

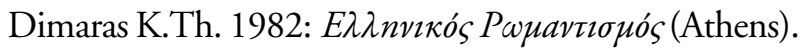

Espagne M. \& Pécout G. 2005: Introduction, in: Espagne M. \& Pécout G. (eds), Philhellénismes et transferts culturels dans l'Europe du XIXe siècle, Revue Germanique Internationale, 1-2.

Étienne R. \& Étienne F. 1990: La Grèce antique. Archéologie d'une Découverte (Paris).

Favaretto I. \& Ravagnan G.L. (eds) 1997: Lo statuario pubblico della Serenissima. Due secoli di collezionismo di antiquità, 1596-1797(Venezia).

Finley M.I. \& Bailey C. 1992: L'Héritage de la Grèce et de Rome (Paris).

Franzoni C. 1984: 'Rimembrare di infinite cose'. Le collezioni rinascimentali di antichità, in: Settis S. (ed.), $M e$ moria dell'Antico nel'Arte Italiana I (Turin) 304-60.

Gazi A. 1990: Museums and National Cultural Property II: The Parthenon Marbles, Museum Management and
Curatorship 9(3), 240-55.

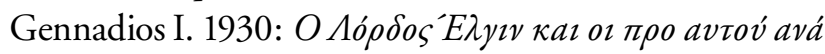

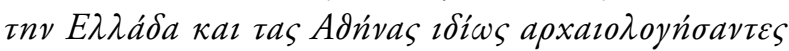

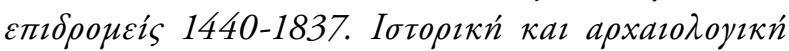

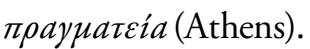

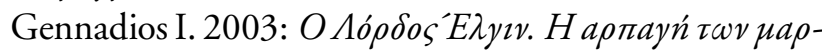
$\mu a ́ \rho \omega v$ (Athens).

Gottmann J. 1973: The Significance of Territory (Charlottesville).

Gourgouris S. 1996: Dream Nation: Enlightenment, Colonization and the Institution of Modern Greece (Stanford).

Gran-Aymerich E. 2007: Les Chercheurs du Passé 17981945: Naissance de l'Archéologie moderne. Dictionnaire biographique d'archéologie (Paris).

Grivaud G. 2001: (ed.), Les Mishellénismes. Actes du séminaire organizé à l'École Française d'Athènes (16-18 mars 1998) (Paris and Athens).

Hamilakis Y. \& Yalouri E. 1999: Sacrilizing the Past: the cults of archaeology in modern Greece, Archaeological Dialogues 6(2), 115-60.

Hamilton Smith A. 1916: Lord Elgin and his Collections, Journal of Hellenic Studies 36, 163-372.

Hartog F. 2003: Régimes d'Historicité. Présentisme et Expérience du Temps (Paris).

Herzfeld M. 1987: Anthropology Through the LookingGlass: Critical Ethnography in the Margins of Europe (Cambridge, MA).

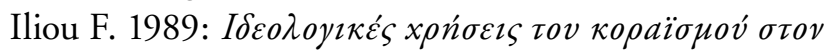
$20 o ́$ aıćva (Athens).

Jenkins R. 1961: The Dilessi Murders (London).

Kalpaxis Th. 1990: A

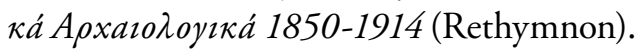

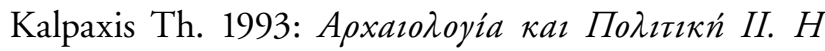

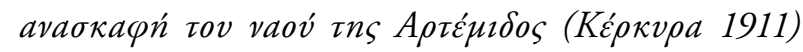
(Rethymnon).

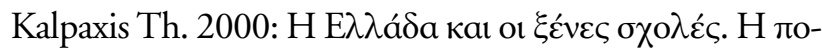

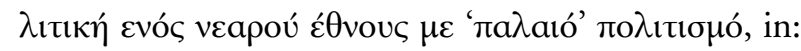
Les politiques de l'archéologie, du milieu du XIXe siècle à l'orée du XXIe. Colloque organisé par l'EFA à l'occasion de la célébration du 150e anniversaire de sa fondation. Textes réunis et édités par R. Étienne (Paris) 9-15.

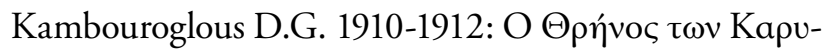

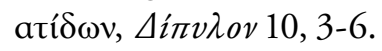

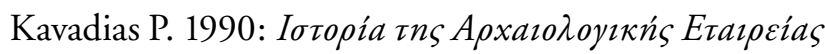




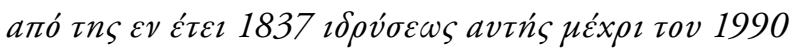
(Athens).

Kitromilides P. 2003: From subservience to ambivalence: modern Greek attitudes towards the Classics, in: Haagsma M. et al. (eds), The Impact of Classical Greece on European and National Identities (Amsterdam) 47-53.

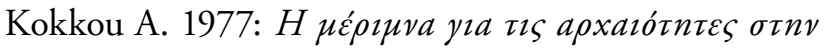

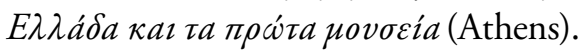

Korais A. 1803 : Mémoire sur l'état actuel de la civilisation dans la Grèce (Paris).

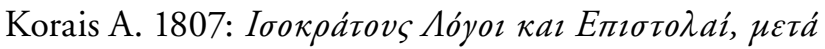

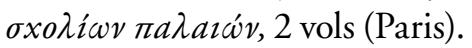

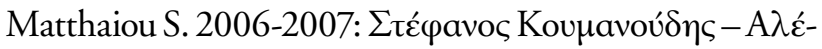

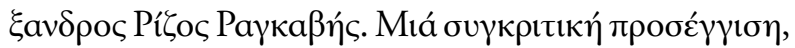
Mvńuwv 28, 169-208.

Michaelis A. 1882: Ancient Marbles in Great Britain (Cambridge).

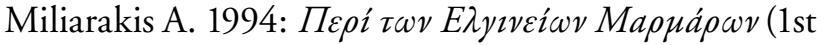
edition 1888, 2nd edition with an introduction by A.G. Kalogeropoulou; Athens).

Pomian K. 1999: Sur l'Histoire (Paris).

Pomian K. 1987: Collectioneurs, amateurs et curieux. Paris-Venise: XVIe-XVIIe siècle (Paris).

Rodocanachi E. 1899: Bonaparte et les Illes Ioniennes: un Épisode des Conquêtes de la République et du Premier Empire (1797-1816) (Paris).

Sack R.D. 1986: Human Territoriality: its Theory and History (New York).

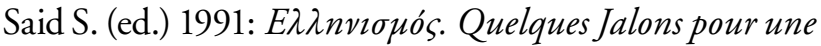
Histoire de l'Identité grecque, Actes du colloque de Strasbourg, 25-27 octobre 1989 (Leiden and Cologne).

Schnapp A. 1993: La conquête du passé. Aux origines de l'archéologie (Paris).

Shanks M. 1996: Classical Archaeology of Greece: Experiences of the Discipline (London and New York).

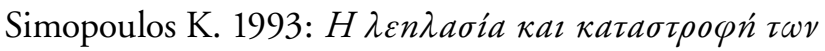

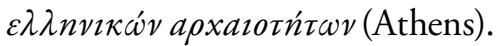

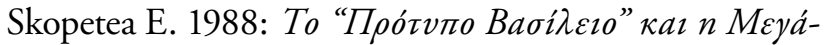

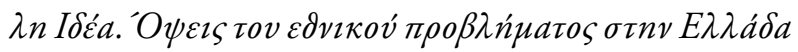
(1830-1880) (Athens).

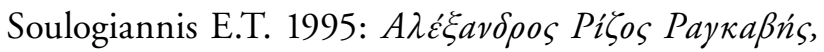

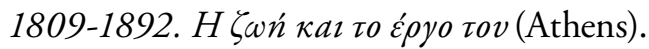

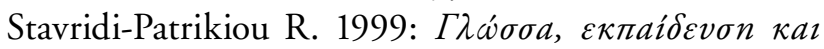

подıгıкn'(Athens).

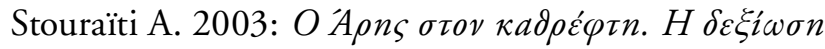

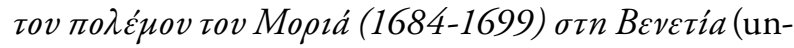
published $\mathrm{PhD}$ thesis, University of Athens).

Tolias G. 1997: La Médaille et la Rouille: Images de la Grèce moderne dans la Presse littéraire parisienne, 1796-1815 (Paris and Athens).

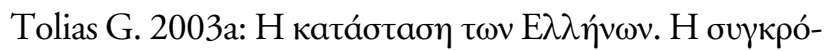

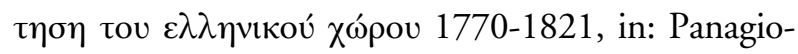

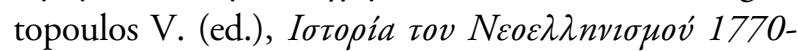
2000 I(Athens) 59-74.

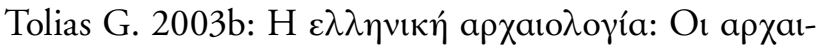

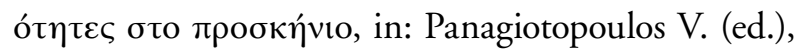

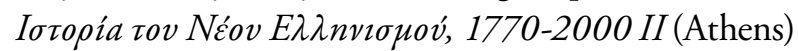
172-78.

Tolias G. 2008: La crise du Philhellénisme: les interlocuteurs Grecs de Joseph Reinach (1878), in: Basch S. - Espagne M. (eds), Les Frères Reinach (Paris) 516-32.

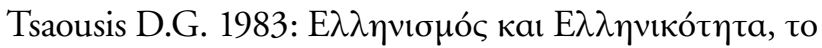

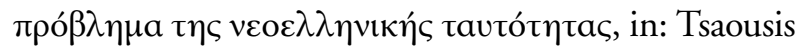

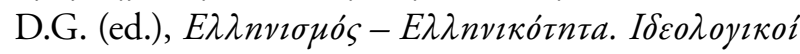

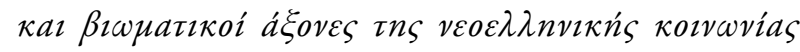
(Athens) 15-16.

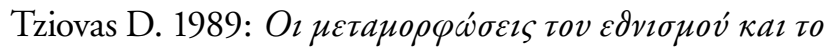

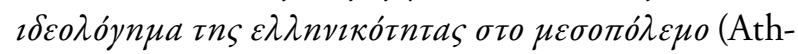
ens).

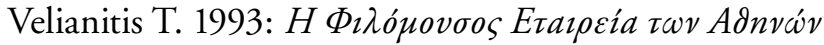
(Athens).

Veloudis G. 1982: O Jakob Philipp Fallmerayer кaı $n$ y'́-

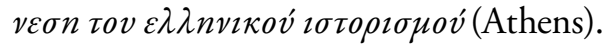

Venturi F. 1979: Settecento Riformatore, vol. III: La prima crisi dell Antico Regime (1768-1776) (Turin).

Walton F.R. 1964: Portrait of a Bibliophile XII: Joannes Gennadius, 1844-1932, The Book Collector (Autumn) 305-26.

Weiss R. 1988: The Renaissance Discovery of Classical Antiquity (Oxford).

White G.W. 2000: Nationalism and Territory: Constructing Group Identity in Southeastern Europe (Lanham, Maryland and Oxford).

Wood R. 1775: A Treatise on the Original Genius and Writings of Homer (London).

Yalouri E. 2001: The Acropolis: Global Fame, Local Claim (Oxford). 
